\title{
【奨励賞研究】
}

\section{平行リンクとロッカ一機能を用いた 歩行メカニズムによる歩行モデルの開発}

\author{
蝋崎 雅佳 \\ 富山県立大学大学院 工学研究科 知能デザイン工学専攻
}

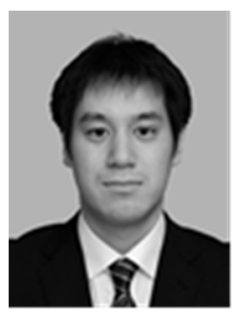

\section{1. 緒言}

二関節筋を関節から他の関節一のエネルギあるいは力(トルク)の 伝達要素として位置付け, 二関節筋の機能を実現する機構として平 行リンク機構を用いた下肢モデルが提案されてきた ${ }^{1)}$. また, 平行り ンク機構が歩行の研究に応用されてきて, ヒトの歩行の分析からロッ カー機能に注目した歩行メカニズムの研究が進められた 2).

本研究では, ヒトの二関節筋を平行少ンク機構に置き換えた歩行メ カニズムを考案し, 歩行モデルを製作した. 歩行モデルを用いて, 両脚歩行で行われる姿勢や力といった歩行に必要な力の伝達が行 われているかを考察した。

\section{2. トルク伝達効果とロッカ一機能}

ヒ下下肢大腿部の二関節筋の特性としてトルク伝達効果があげられ る. この機能を用いて, 平行リンク機構に置き換えることで, 平行リン ク機構の特性である抗重力, 推進力発生を得ることができる.この二 つの働きによって, 衝撃の吸収, 推進する力が働 ${ }^{11}$.

また, 踵, 足関節, 前足部, つま先と連続的に回転軸として機能寸 ることで, 滑らかな歩行を可能にするロッカー機能が働く.その効果 として身体の安定性や推進力の生成, 衝撃の吸収があげられる2).

\section{3. 歩行モデル}

製作した歩行モデルを Fig. 1 に示す. 歩行動作に必要な力を平行 リンク機構による関節間のトルク伝達機能によって得ることができ, そ の力によって歩行の推進力が発生しロッカー機能によって制御され る. 歩行モデルは, リンク端の回転関節 $\mathrm{J}_{3}$ となる踵, 足関節, 前足部 に対応したリンク機構を構成寸ることができる脚を上体につなげ, 股 関節 $\mathrm{J}_{1}$ のトルクによって歩行を行う. リンク機構は, 各ロッカー機能に 対応するように構成要素にばねを含む 3 つのリンク L L f $\mathrm{g}(\mathrm{H}, \mathrm{A}, \mathrm{F})$ を有す る. それぞれのリンク機構が連続的に独立して機能寸るようにした.

歩行モデルを用いて床反力計測を行い, 左右の脚の床反力から 力の発生と伝達を確認した. 測定結果を Fig. 2 に示寸. 垂直方向は 上向きの力を正に, 水平方向は進行方向を正の向きとして考える. 垂直方向の床反力では, 左右の脚の両方に二峰性が確認できる. 右足の遊却期の移り変わりに注目すると, 右足の蹴り出しの水平方 向の大きさは, 左足の接地の水平方向の大きさよりも大きく, 進行方 向に向けて力が働く.この力によって, 両脚歩行モデルは停止する ことなく歩行を行うことができることが明らかになった。

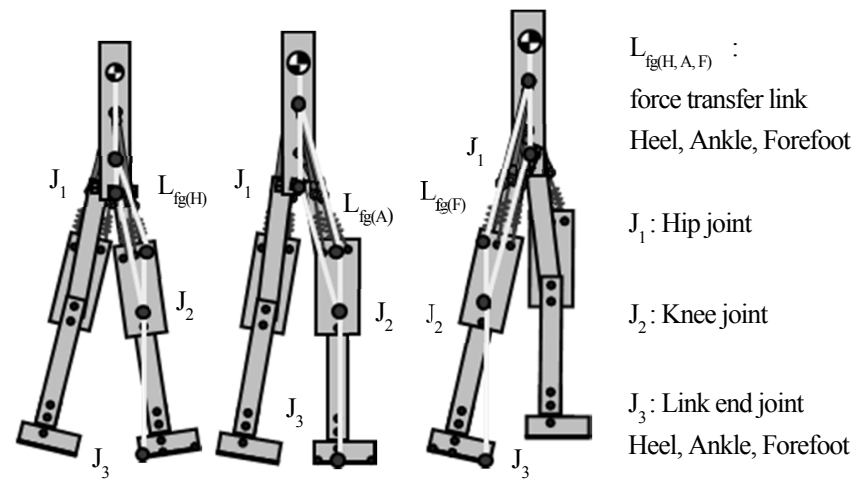

Fig. 1 Mechanical model

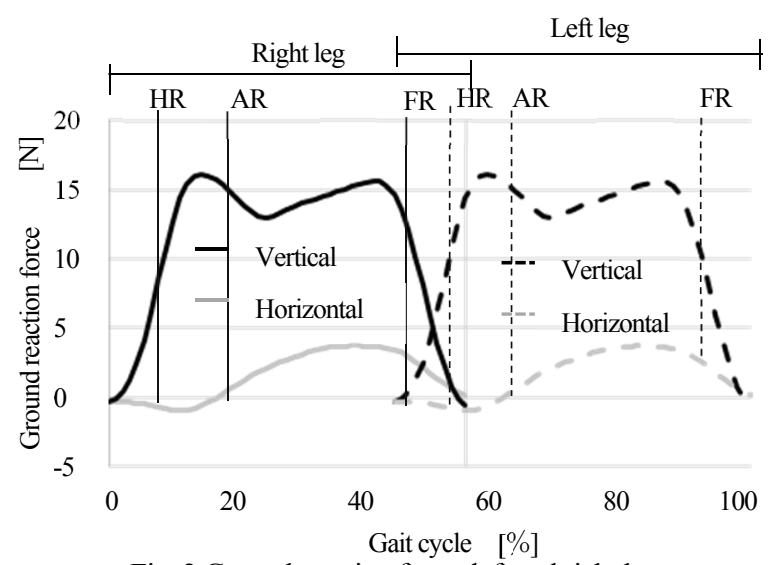

Fig. 2 Ground reaction force: left and right legs

\section{4. まとめ}

本研究では, 平行リンク機構とロッカー機能による歩行モデルとし て, 両脚歩行モデルを製作し, その歩容を評価した. 床反力から, 接 地側に発生する力の反対側下肢への伝達が確認され, 単脚で完結

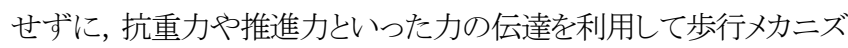
ムによる歩行が観測できた。

\section{参考文献}

1）大島 徹, 藤川智彦, 小柳健一, 増田寬之, 本吉達郎. 脚の二 関節筋を機構要素とした平行リンク機構による運動制御，日本 機械学会ロボティクス・双ロニクス講演会 2016 予稿集, CDROM 2P2-11b2, (2016).

2）衣笠哲也, 大須賀公一, 土師貴史. 受動歩行ロボットのす寸め 一重力だけで 2 足歩行するロボットのつくりかた一. 第 1 版. 東 京都:コロナ社, 2016, pp5-29. 